\title{
INFLUENCE OF CYANOBACTERIAL BLOOM ON FRESHWATER BIOCOENOSIS. USE OF BIOASSAYS FOR CYANOBACTERIAL MICROCYSTINS TOXICITY ASSESSMENT
}

\author{
Marlena PIONTEK ${ }^{1}$, Wanda CZYŻEWSKA ${ }^{2}$ \\ ${ }^{1}$ Univeristy of Zielona Góra, Zielona Góra, Poland \\ ${ }^{2}$ Water and Wastewater Plant in Zielona Gora, Poland Sp. z o.o., Poland
}

\begin{abstract}
The issues presented in this study concern a very important problem of the occurrence of cyanobacterial blooms in surface water used for water supply purposes. The objective of this study was to analyze the occurrence of cyanotoxic risk in the catchment area of the Obrzyca River (including Sławskie lake which is the beginning of the river), which is a source of drinking water for the inhabitants of Zielona Góra. In order to evaluate toxicity of cyanobacterial bloom it was conducted toxicological testing using aquatic invertebrates (Daphnia magna, Dugesia tigrina) and heterotrophic bacteria (Escherichia coli, Enterococcus faecalis, Pseudomonas fluorescens). Test samples were collected from May to October, 2012. The most toxic was a sample collected from Lake Sławskie on $20^{\text {th }}$ October when cyanobacteria bloom with a predominance of Microcystis aeruginosa occurred and the amount of microcystins was the largest. The methanol extract of the sample was toxic only above a concentration of $6 \cdot 10^{3} \mathrm{mg} \cdot \mathrm{dm}^{-3}$. The lethal concentration (48-h LC 50) for Daphnia magna was $3.09 \cdot 10^{3}$ and for Dugesia tigrina (240-h LC 50) $1.51 \cdot 10^{3} \mathrm{mg} \cdot \mathrm{dm}^{-3}$ of microcystins (MC-LR, MC-YR and MC-RR). The same extract stimulated growth of Escherichia coli and Enterococcus faecalis cells.
\end{abstract}

Keywords: cyanobacteria, cyanotoxins toxicity, bioassays

\footnotetext{
${ }^{1}$ Corresponding author: University of Zielona Gora, Institute of Environmental Engineering, Szafrana st 15, 65-246 Zielona Góra, Poland, e-mail: m.piontek@ iis.uz.zgora.pl tel. +48683282679

2 Corresponding author: Water and Wastewater Plant in Zielona Gora Poland Sp. z o.o., Zjednoczenia st 120A, 65-120 Zielona Góra, Poland
} 


\section{INTRODUCTION}

\subsection{Negative effects of cyanobacteria and their blooms on water biocoenosis}

Apart from the positive significance of cyanobacteria (pioneer organisms, production of oxygen, contribution to the carbon and the nitrogen biogeochemical cycles, ability to grow in highly polluted environments, biofuel production) their excessive number unprofitably affects aquatic biocoenosis $[21,30]$. Cyanobacteria successfully compete with other algae for nutrients and light access [30]. Some adaptive abilities, i.e. $\mathrm{N}_{2}$ - fixation, vertical movements due to the presence of gas vacuoles (planktonic cyanobacteria) or low light requirements, as well as various defense mechanisms, cause that cyanobacteria are enable to colonize various environments as a first organisms $[11,45]$.

Cyanobacteria may constitute a food source for herbivorous zooplankton; however, this is poor quality and may even constitute a threat to the consumer's life [14]. The directly negative effect of cyanobacteria on aquatic animal organisms (e.g. rotifers, cladocerans, copepods) may result from mechanical disruption in the filtration process of grazers or cause negative influence growth rate or lower reproduction of zooplankton [11]. Cyanobacteria may indirectly affect freshwater plankton via changes in abiotic conditions (deficiency of oxygen, $\mathrm{pH}$ ), allelopathic inhibition of the growth of algae which are a complete food for zooplankton, and also planktonic animals pushing to lower zones of reservoirs $[11,35,50]$.

Via the food chain, (cyanotoxins, CYA) constitute a lethal threat for aquatic bioceonosis, and indirectly also for humans, who consume seafood (fish, crayfish, shrimps, clams, snails, crabs) [14]. Cyanobacteria toxins in doses lower than lethal ones may be accumulated in organisms and cause poisoning in consumers. [32] Consumption of poisoned seafood may in some cases exceed the TDI (Tolerable Daily Intake) which was established for microcystin LR (MC-LR) 0.04 $\mu \mathrm{g} \cdot \mathrm{kg}^{-1}$ b.w./day, and for cylindrospermopsin $(\mathrm{CYN}) 0.03 \mu \mathrm{g} \cdot \mathrm{kg}^{-1}$ b.w./day. Therefore, cyanotoxin monitoring only in drinking water may not reflect the actual cyanotoxic threat [14]. Table 1 presents examples of seafood poisoning. Cyanotoxins may accumulate in fish bodies as a result of: direct consumption (silver carp eating phytoplankton), direct contact between the skin and extracellular toxins or indirect consumption of food intoxicated with cyanotoxins (flounders eating blue clams containing cyanobacteria toxins). Intoxication with anotoxins depends on the kind of fish nutrition. The oral pathway is of the highest significance in fish intoxication [23]. The amount of toxins derived from cyanobacteria is lower in carnivorous fish compared to herbivorous ones. The content of cyanotoxins in invertebrates tissues differed depending on the time of sampling and was higher in August than in November [32]. 
INFLUENCE OF CYANOBACTERIAL BLOOM ON FRESHWATER BIOCOENOSIS. USE OF BIOASSAYS FOR CYANOBACTERIAL MICROCYSTINS TOXICITY ASSESSMENT

Table 1. Cyanotoxins in seafood consumed by humans

\begin{tabular}{|c|c|c|c|c|c|}
\hline Organism & $\begin{array}{l}\text { Observed } \\
\text { CYA* }\end{array}$ & $\begin{array}{c}\text { Cyanotoxin } \\
\text { concentration } \\
{\left[\mu \mathrm{g} \cdot \mathrm{g}^{-1}\right]} \\
(\text { organ } / \text { tissue) }\end{array}$ & $\begin{array}{c}\text { Daily intake } \\
{\left[\mu \mathrm{g} \cdot \text { day }^{-1}\right]}\end{array}$ & $\begin{array}{l}\text { Multiplicity } \\
\text { of TDI }\end{array}$ & References \\
\hline \multicolumn{6}{|c|}{ FISH } \\
\hline $\begin{array}{c}\text { Hypophthalm } \\
\text { ichthys } \\
\text { molitrix } \\
\end{array}$ & $\mathrm{MCs}$ & (muscles) & $\begin{array}{l}\text { Not specified } \\
\text { (n.s.) }\end{array}$ & n.s. & [1] \\
\hline \multirow{2}{*}{$\begin{array}{c}\text { Perca } \\
\text { fluvialitis }\end{array}$} & ANA-a & $\begin{array}{c}0.04 \text { (muscles) } \\
8.91 \text { (liver) }\end{array}$ & \multirow{2}{*}{ n.s. } & \multirow{2}{*}{ n.s. } & \multirow{2}{*}{ [34] } \\
\hline & $\mathrm{MCs}$ & $\begin{array}{c}0.22 \text { (muscles) } \\
8.81 \text { (liver) }\end{array}$ & & & \\
\hline \multirow{2}{*}{$\begin{array}{l}\text { Carassius } \\
\text { gibellio }\end{array}$} & ANA-a & $\begin{array}{c}0.14 \text { (muscles) } \\
3.12 \text { (liver) }\end{array}$ & \multirow{2}{*}{ n.s. } & \multirow{2}{*}{ n.s. } & \multirow{2}{*}{ [34] } \\
\hline & $\mathrm{MCs}$ & $\begin{array}{c}0.13 \text { (muscles) } \\
3.12 \text { (liver) }\end{array}$ & & & \\
\hline \multirow{2}{*}{$\begin{array}{r}\text { Rutilus } \\
\text { rutilus }\end{array}$} & ANA-a & $\begin{array}{c}0.04 \text { (muscles) } \\
7.24 \text { (liver) }\end{array}$ & \multirow{2}{*}{ n.s. } & \multirow{2}{*}{ n.s. } & \multirow{2}{*}{ [34] } \\
\hline & $\mathrm{MCs}$ & $\begin{array}{c}0.35 \text { (muscles) } \\
7.24 \text { (liver) }\end{array}$ & & & \\
\hline $\begin{array}{l}\text { Cyprinus } \\
\text { carpio }\end{array}$ & $\mathrm{MCs}$ & $\begin{array}{c}1.08 \text { (liver) } \\
0.57 \text { (kidney) } \\
0.14 \text { (muscle) }\end{array}$ & 0.04 & n.s. & [29] \\
\hline $\begin{array}{l}\text { Platichtys } \\
\text { flessus }\end{array}$ & NOD & $\begin{array}{l}0.1 \text { (muscle) } \\
1.10 \text { (liver) }\end{array}$ & 1.5 & 0.6 & [47] \\
\hline $\begin{array}{l}\text { Rutilus } \\
\text { rutilus }\end{array}$ & NOD & $\begin{array}{c}0,2 \text { (muscle) } \\
0,9 \text { (liver) }\end{array}$ & 3 & 1.3 & [47] \\
\hline \multicolumn{6}{|c|}{ CLAMS } \\
\hline $\begin{array}{c}\text { Cristaria } \\
\text { plicata }\end{array}$ & \multirow{3}{*}{ MCs } & $\begin{array}{c}0.023 \\
\text { (foot/muscle) }\end{array}$ & 6.9 & 2.9 & \multirow{3}{*}[3,6]{} \\
\hline $\begin{array}{l}\text { Hyriopsis } \\
\text { cumingii, }\end{array}$ & & $\begin{array}{c}0.188 \\
\text { (whole) }\end{array}$ & 56.4 & 23.5 & \\
\hline $\begin{array}{c}\text { Lamprotula } \\
\text { leai }\end{array}$ & & $\begin{array}{c}0.058 \\
\text { (foot muscle) }\end{array}$ & 17.4 & 7.3 & \\
\hline $\begin{array}{c}\text { Anodonta } \\
\text { cygnea }\end{array}$ & MC-LR & $\begin{array}{c}0,29-1,51 \\
\text { (organs, } \\
\text { mantle, foot) }\end{array}$ & n.s. & n.s. & [32] \\
\hline \multicolumn{6}{|c|}{ SNAILS } \\
\hline $\begin{array}{c}\text { Bellamya } \\
\text { aeruginosa. }\end{array}$ & $\begin{array}{l}\text { MC-LR, } \\
\text { MC-RR }\end{array}$ & $\begin{array}{c}\text { bile ducts, } \\
\text { digestive tract }\end{array}$ & n.s. & n.s. & [5] \\
\hline $\begin{array}{l}\text { Viviparus } \\
\text { contectus }\end{array}$ & MC-LR & $\begin{array}{c}0,64-1,22 \\
\text { (whole) }\end{array}$ & n.s. & n.s. & [32] \\
\hline \multicolumn{6}{|c|}{ SHRIMPS } \\
\hline $\begin{array}{c}\text { Palaemon } \\
\text { modestus }\end{array}$ & $\begin{array}{l}\text { MC-LR, } \\
\text { MC-RR }\end{array}$ & $\begin{array}{c}0.026 \\
\text { (muscle) }\end{array}$ & 7.8 & 3.3 & [4] \\
\hline
\end{tabular}




\begin{tabular}{|l|c|c|c|c|c|}
\hline $\begin{array}{c}\text { Macrobrac } \\
\text { hium } \\
\text { nipponensis }\end{array}$ & $\begin{array}{c}\text { MC-LR, } \\
\text { MC-RR }\end{array}$ & $\begin{array}{c}0.012 \\
\text { (muscle) }\end{array}$ & 3.6 & 1.5 & [4] \\
\hline $\begin{array}{c}\text { Atyaephyra } \\
\text { desmaresti }\end{array}$ & MC-LR & $\begin{array}{c}0,67-2,40 \\
\text { (whole) }\end{array}$ & n.s. & n.s. & [32] \\
\hline
\end{tabular}

*cyanotoxins: MC-microcystin; ANA - anatoxin; NOD - nodularin, n.s. - not specified

The presence of herbivorous fish, such as carp, in water with cyanobacteria blooms and feeding on them leads to histopathological changes mainly in fish kidneys, liver and stomach [29]. Mass development of cyanobacteria in waters is also of a high significance for invertebrates - clams, mollusks. Three variants (MC-LR, MC-RR, MC-YR) in three clam species, Cristaria plicata, Hyriopsis cumingii, Lamprotula leai, have been observed during mass cyanobacteria blooms. The highest concentrations of microcystins were noted in the digestive gland, intestine and leg. Clam intoxication occurrence constitutes a significant health problem for their consumers [6]. MC-LR equivalent was detected in Anodonta cygneaclams mainly in the organs, mantle and foot [32]. Other mollusks, such as snails, are also not neutral to an excessive amount of cyanobacteria in water. The presence of microcystins MC-LR and MC-RR has been observed in a snail from the Bellamya genus, mainly in bile and digestive tracts. Despite the fact that these parts are removed prior consumption and do not pose a threat for humans, poisoned snails constitute a danger for trophic groups feeding on them (amphibians, mammals, birds) [5]. Cases of cyanotoxin presence have also been noted in tissues or organs of crayfish, shrimps and crabs. This confirms the fact that eating poisoned seafood may constitute a danger for human health [14]. The toxic effect of cyanotoxins on numerous organisms of aquatic biocoenosis has been demonstrated [6].

\subsection{The occurrence of cyanobacteria blooms in the Obrzyca River catchment area, a source of drinking water}

One of the sources of raw water for Zielona Gora water supply system is the surface water drawn from the Obrzyca River (Sławskie Lake is the beginning of the river), which is used for supplying the population (mainly of the town of Zielona Góra) with drinking water and treated in Water Treatment Plant in Zawada (WTP 'ZAWADA'). Therefore the quality of water in the river and the lake is of vital importance, especially in the context of the potential presence of toxic cyanobacteria $[28,42,43]$. In September 1994 at WTP microstrainers were installed in order to reduce the amount of phytoplankton, including cyanobacteria, in raw water from the Obrzyca River [42, 43]. The efficiency of the microstraining process in the removing of cyanobacteria reaches up to $90 \%$. The use of a nonreactive process of microstraining as a pretreatment process of algae rich water purification is justified because it reduces the amount of side chain precursors of 
oxidation products and indirectly, by reducing the amount of cyanobacteria, decreases the contents intracellular cyanotoxins [28, 42, 43].

This study was aimed at assessing potential threat from cyanobacteria and determining the concentrations of microcystins along the catchment area of the Obrzyca River from its beginning (Sławskie Lake) to the drinking water intake. In order to evaluate toxicity of cyanobacterial bloom occurred in water which is source of drinking water, it was conducted toxicological tests using aquatic invertebrates (Daphnia magna, Dugesia tigrina) [44] and heterotrophic bacteria (Escherichia coli, Enterococcus faecalis, Pseudomonas fluorescens). Previous reports concerning the toxic effect of cyanotoxins on water crustacea $[2,7,8,10]$ and the usefulness of turbellarians in toxicological study were the basis for this study [37, 38, 40]. Bacteria, due to their short generation time, [are often used as bioindicators [48]. The advantage of bacterial tests is their fast and simple execution and therefore were also used in the study.

\section{MATERIALS AND METHODS}

\subsection{Sample collection}

The samples from the River Obrzyca and its tributaries were collected once a month (from May to October) in 2012 at six sites located in the following localities: Sadowo, Ostrzyce, Chwalim, Wojnowo, Uście, and Lubiatów. Because of visual bloom in Sławskie Lake (which feeds the Obrzyca River) it was sampled on $20^{\text {th }}$ October 2012 additionally five specimens (L2, L3, L4, L5, L6) (Fig. 1, Table 3). Samples were collected from the surface $(0-0,5 \mathrm{~m})$ water layer (pelagic zone of the lake).

\subsection{Sample preparation for the examinations}

Samples for phytoplankton counting analysis were collected in volumes of $10 \mathrm{dm}^{3}$ using a bucket graduated volumetric, and then they were filtered through a plankton net with a mesh diameter of $10 \mu \mathrm{m}$ (final volume was up to $0.25 \mathrm{dm}^{3}$ ) [42]. In order to determine the intracellular MC-LR equivalent using the ELISA method, and toxicological analysis, the samples were filtered through a GF/C fiberglass filter (Whatmann). The target volume of filtered sample was $0.50 \mathrm{dm}^{3}$. Next, collected precipitate was frozen at a temperature of $-20^{\circ} \mathrm{C}$ [17]. After threetimes thawing, the filters with filtered precipitate were dried at room temperature, then poured with $75 \%$ methanol (ca. $0.005 \mathrm{dm}^{3}$ ) and stored at a temperature of $2-8^{\circ} \mathrm{C}$. After $24 \mathrm{~h}$, the samples were homogenized manually by filter grinding, and then they were centrifuged using an MPW-350e centrifuge (MPW, Poland) at $4000 \mathrm{rpm}$ for $10 \mathrm{~min}$. Supernatant was removed and completed with deionized 
water up to the volume before the filtration [43]. Research material prepared this way was used in the ELISA test and in toxicological examinations.

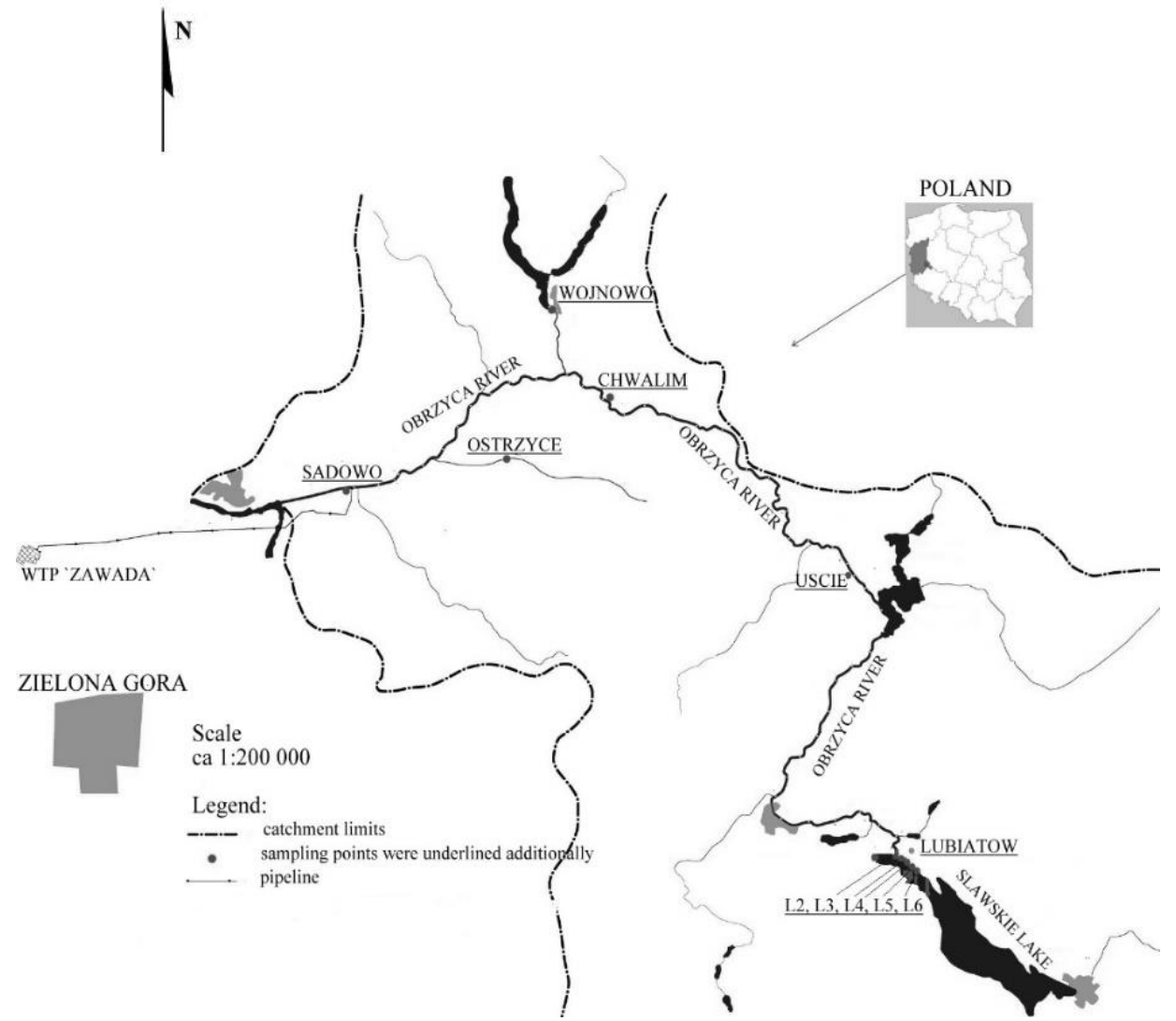

Fig. 1. Research area

\subsection{Methods of analysis}

\subsubsection{Hydrobiological analysis}

Analyzes of cyanobacterial abundance and taxonomic composition were performed using a Sedgewick Rafter chamber of a volume of $0.001 \mathrm{dm}^{3}$ in a specified number of fields of view for the following parameters: height $1 \mathrm{~mm}$, area $1 \mathrm{~mm}^{2}$. The observations were performed using an MN 358/A microscope (OPTA-TECH, Poland). Cyanobacterial specimens counting was made at $160 \mathrm{x}$ magnification, and the determination of cyanobacterial species was conducted at 640x magnification. The whole colonies or trichomes, were counted during the analysis, and the result was provided as thousands of organisms per liter $\left(10^{3} \mathrm{org} \cdot \mathrm{dm}^{-3}\right)[42]$. Cyanobacteria amount (colonies, trichomes) exceeding value $500 \cdot 10^{3} \mathrm{org} \cdot \mathrm{dm}^{-3}$ was reffered as bloom [43]. 


\subsubsection{ELISA}

Ready tests (Abraxis) were used in order to determine the MC-LR equivalent. Absorbance of all the samples was read at wavelengths of $450 \mathrm{~nm}$ and $605 \mathrm{~nm}$ using a DR 5000 spectrophotometer $(\mathrm{HACH}$, Germany). The percentage of relative inhibition of standards or samples with respect to the negative control (\% Bo) was calculated after spectrophotometric measurement. MC-LR equivalent in test samples was determined using a standard curve made based on \% Bo results. The detection limit was $0.15 \mu \mathrm{g} \cdot \mathrm{dm}^{-3}$ (ABRAXIS manufacturer's manual). The studies were conducted in triplicate.

\subsubsection{Toxicological tests}

Toxicological tests with invertebrates were conducted using Daphnia magna Straus (D. magna) and Dugesia tigrina Girard (D. tigrina). Test organisms were derived from the culture of the laboratory of the Institute of Environmental Engineering (University of Zielona Góra). Acute toxicity, LC 50, for test organisms was determined using the tests with invertebrates. A condition test with potassium dichromate $\left(\mathrm{K}_{2} \mathrm{Cr}_{2} \mathrm{O}_{7}\right)$ was conducted for each research series in order to verify the physiological state of the tested organisms [41]. Toxicological analysis with daphnids and turbellarians involved methanol extracts of 35 samples and MC-LR standard of a concentration of $10^{3} \mu \mathrm{g} \cdot \mathrm{dm}^{-3}$.

Experimental biotests with bacteria for an evaluation of examined extract toxicity were conducted using the following strains: Pseudomonas fluorescens ATCC 13525 (Ps. fluorescens), Enterococcus faecalis ATCC 19433 (E. faecalis), and Escherichia coli ATCC 25922 (E. coli). Bacteria as a bioindicator were used for an evaluation of only one sample toxicity where the amount of microcystins was the highest derived from Sławskie Lake (sample 35, table 3). and for MC-LR standard of a concentration of $2 \cdot 10^{3} \mu \mathrm{g} \cdot \mathrm{dm}^{-3}$. The basis for an evaluation of the toxic effect of examined sample were the concentrations of the extracts, in which cell proliferation was inhibited by $50 \%$ (result as IC 50), or were stimulated (proliferation stimulation) (own method).

\section{Evaluation of the acute toxicity, LC 50, of the extracts using Daphnia magna}

Cladocerans were cultured in aquaria of a volume of $10 \mathrm{dm}^{3}$ at a temperature of $20 \pm 2^{\circ} \mathrm{C}$ with fluorescent lightning $3000 \mathrm{~lx}$, under a light: dark cycle - 12:12h. The food for daphnids was composed mainly of algae (Scenedesmus ssp. and Chlorella ssp.) and dried baker's yeasts. Biotests were conducted using 3-day old organisms [36].

Standard water of a following composition: $294 \mathrm{mg} \cdot \mathrm{dm}^{-3} \mathrm{CaCl}_{2} \cdot \mathrm{H}_{2} \mathrm{O}$; $123 \mathrm{mg} \cdot \mathrm{dm}^{-3} \mathrm{MgSO}_{4} \cdot 7 \mathrm{H}_{2} \mathrm{O} ; 63.0 \mathrm{mg} \cdot \mathrm{dm}^{-3} \mathrm{NaHCO}_{3} ; 5.50 \mathrm{mg} \cdot \mathrm{dm}^{-3} \mathrm{KCl}$ [9], was 
used for cyanobacteria extract dilutions and for control sample. A series of dilutions (MC-LR concentrations were as follows: 6.0; 5.0; 4.2; 3.5; 2.9; 2.4; $2.0 ; 1.7 \mu \mathrm{g} \cdot \mathrm{dm}^{-3}$ ) of test samples were made in 3 replications in flasks of a volume of $0.05 \mathrm{dm}^{3}$ and control samples were placed in standard water. Tested organisms were added in amounts from 10 to 12 individuals to test tubes of a volume ca. $0.045 \mathrm{dm}^{3}$ filled with prepared dilutions. Dead individuals were counted after a $48 \mathrm{~h}$ incubation period. The results of the tests were used for LC 50 calculation for D. magna in the treatments. The graphical method (probit analysis) was used in order to calculate 48-h LC 50 values [49]. The straight line was verified in terms of its localization correspondence to the empirical points using the $\chi^{2}$ test which is based on Pearson's criterion [49]. The examined distributions were accepted as consistent enough with the normal distribution, when the probability determined in the $\chi^{2}$ test was higher than 0.7 [49]. The confidence interval was specified based on Student's t-distribution. A confidence interval of 0.95 was accepted in all toxicological calculations.

\section{Experiment with the application of turbellarian Dugesia tigrina for cyanobacteria toxicity evaluation}

The experiment was conducted in a laboratory room of a temperature of $20 \pm 2^{\circ} \mathrm{C}$. The tests involved individuals cut into two parts above the throat $[37,38]$. A series of test sample dilutions (MC-LR concentrations were as follows: 4.0; 3.3; 2.8; $2.3 ; 1.9 ; 1.6 ; 1.3 ; 1.1 \mu \mathrm{g} \cdot \mathrm{dm}^{-3}$ ) in 3 replications were made in flasks of a volume of $0.050 \mathrm{dm}^{3}$. Next, test solutions of a volume of ca. $0.045 \mathrm{dm}^{3}$ were poured into flasks of a volume of $0.050 \mathrm{dm}^{3}$. Ten cut individuals were introduced into each flask, i.e. five turbellarians (about $12 \mathrm{~mm}$ long) divided into two parts above the throat $[37,38]$. The tests were made in three parallel series with control samples (water for dilutions as in the test with daphnia). The number of dead individuals was determined after $240 \mathrm{~h}$. The results of the observations were the basis for the 240-h LC 50 calculation [39]. The graphical method (probit analysis) was used in order to calculate the LC 50 value [49].

\section{Experiment with the application of heterotrophic bacteria for cyanobacteria toxicity evaluation}

The strains of heterotrophic bacteria were cultured on an agar with yeast extract. The cultures were incubated at a temperature of $22 \pm 2^{\circ} \mathrm{C}$ for Ps. fluorescens, or $36 \pm 2^{\circ} \mathrm{C}$ for $E$. faecalis and $E$. coli for $24 \mathrm{~h}$, then they were stored at a temperature of $5 \pm 3^{\circ} \mathrm{C}$ and cultured on a fresh medium once a week. A suspension where the optical density corresponded to an absorbance of 0.2 with a light wavelength of $610 \mathrm{~nm}$ was made after medium preparation for the culture [26]. The test was conducted in triplicate according to the scheme presented in Table 2. 
INFLUENCE OF CYANOBACTERIAL BLOOM ON FRESHWATER BIOCOENOSIS. USE OF BIOASSAYS FOR CYANOBACTERIAL MICROCYSTINS TOXICITY ASSESSMENT

Table 2. Scheme of the series of dilutions for tests with bacteria

\begin{tabular}{|c|c|c|c|c|c|c|c|}
\hline \multirow[b]{2}{*}{ Dilution } & \multirow{2}{*}{$\begin{array}{c}\text { Deionized } \\
\text { water } \\
{\left[\mathrm{cm}^{3}\right]}\end{array}$} & \multirow{2}{*}{$\begin{array}{c}\text { Test } \\
\text { sample } \\
{\left[\mathrm{cm}^{3}\right]} \\
\end{array}$} & \multicolumn{3}{|c|}{ Solutions } & \multirow[b]{2}{*}{$\begin{array}{l}\text { Inoculum } \\
{\left[\mathrm{cm}^{3}\right]}\end{array}$} & \multirow{2}{*}{$\begin{array}{c}\text { Final } \\
\text { volume } \\
{\left[\mathrm{cm}^{3}\right]} \\
\end{array}$} \\
\hline & & & $\begin{array}{c}\mathrm{I} \\
{\left[\mathrm{cm}^{3}\right]}\end{array}$ & $\begin{array}{c}\mathrm{II} \\
{\left[\mathrm{cm}^{3}\right]}\end{array}$ & $\begin{array}{c}\text { III } \\
{\left[\mathrm{cm}^{3}\right]}\end{array}$ & & \\
\hline 0 & 8.00 & 0.00 & 0.25 & 0.25 & 0.5 & 1.0 & 10 \\
\hline 2 & 3.00 & 5.00 & 0.25 & 0.25 & 0.5 & 1.0 & 10 \\
\hline 4 & 5.50 & 2.50 & 0.25 & 0.25 & 0.5 & 1.0 & 10 \\
\hline 8 & 6.75 & 1.25 & 0.25 & 0.25 & 0.5 & 1.0 & 10 \\
\hline 16 & 7.37 & 0.63 & 0.25 & 0.25 & 0.5 & 1.0 & 10 \\
\hline 32 & 7.69 & 0.31 & 0.25 & 0.25 & 0.5 & 1.0 & 10 \\
\hline
\end{tabular}

Then, the samples were incubated at a temperature of $22 \pm 2{ }^{\circ} \mathrm{C}$ (Ps. fluorescens) or $36 \pm 2{ }^{\circ} \mathrm{C}$ (E. faecalis and E. coli) for $16 \pm 1 \mathrm{~h}$, and finally absorbance measurement was made determining the optical density in each sample at a wave length of $\lambda=610 \mathrm{~nm}$. Inhibition of cell proliferation expressed as a percentage was calculated according to the following formula:

$$
\mathrm{IC}=\frac{\mathrm{Bc}-\mathrm{Bn}}{\mathrm{Bc}-\mathrm{Bo}} \times 100
$$

$\mathrm{Bn}$ - absorbance of the examined sample after time $\mathrm{t} ; \mathrm{Bc}$ - absorbance of the control sample after time $t$; Bo - absorbance of the control sample after time $t_{0}$. Significance of the differences between the $\mathrm{Bn}$ value (absorbance o the examined sample after time $\mathrm{t}$ ) and $\mathrm{Bc}$ (absorbance of the control sample after time t) was analyzed in the tests with bacteria using the Student's t-test.

\section{RESULTS OF THE STUDY}

\subsection{Results of hydrobiological examinations}

A total $\mathrm{n}$ number of cyanobacteria in the samples from the Obrzyca river catchment from May to October 2012 ranges from 0.06 to $1130 \cdot 10^{3}$ org. $\mathrm{dm}^{-3}$ (Table 3). The River Obrzyca in Uście, its tributary in Wojnowo and Sławskie Lake constituted sampling sites where cyanobacterial blooms occured most frequently. Limnothrix redekei, was predominant (the most numerous species in a total cyanobacteria numbers) in May in the Obrzyca and its tributaries, in June there was also L. redekei in the Obrzyca in Sadowo, and cyanobacteria: Dolichospermum flos-aquae, Dolichospermum spiroides, Aphanizomenon flosaquae. Aph. flos-aquae was predominant in July in the river, and D. spirodes closer to the water intake (Ostrzyce, Sadowo). In August and September, the predominant species was mainly Planktothrix agardhii. Microcystis aeruginosa was the most abundant in the samples from Lake Sławskie in $20^{\text {th }}$ October 2012 (Table 3). 


\subsection{Results of ELISA tests}

Most examined samples collected from May to July 2012 revealed absence of MC-LR (results under limit detection) (Table 3).

Table 3. Results of hydrobiological and immunoenzymatic analysis

\begin{tabular}{|c|c|c|c|c|c|}
\hline No & $\begin{array}{c}\text { Months of } \\
\text { sampling } \\
\text { [month/year] }\end{array}$ & $\begin{array}{l}\text { Sampling } \\
\text { site }\end{array}$ & $\begin{array}{c}\text { Amount of } \\
\text { cyanobacteria } \\
{\left[10^{3} \text { org. } \cdot \mathrm{dm}^{-3}\right]}\end{array}$ & Dominant species* & $\begin{array}{c}\text { MC-LR } \\
{\left[\mu \mathrm{g} \cdot \mathrm{dm}^{-3}\right]}\end{array}$ \\
\hline 1 & \multirow{6}{*}{$05 / 2012$} & Sadowo & 0.06 & Limnothrix redekei & $<0.15$ \\
\hline 2 & & $\begin{array}{l}\text { Lubiatów } \\
\text { (L2) }\end{array}$ & nd. & $\begin{array}{l}\text { nd. } \\
\text { Nd. }\end{array}$ & $<0.15$ \\
\hline 3 & & Uście & 80.1 & Limnothrix redekei & 1.20 \\
\hline 4 & & Chwalim & 11.7 & Limnothrix redekei & $<0.15$ \\
\hline 5 & & Wojnowo & 0.08 & Limnothrix redekei & $<0.15$ \\
\hline 6 & & Ostrzyce & nd. & nd. & $<0.15$ \\
\hline 7 & \multirow{6}{*}{$06 / 2012$} & Sadowo & 0.25 & Limnothrix redekei & $<0.15$ \\
\hline 8 & & $\begin{array}{c}\text { Lubiatów } \\
\text { (L2) }\end{array}$ & 5.30 & Microcystis viridis & $<0.15$ \\
\hline 9 & & Uście & 606 & $\begin{array}{c}\text { Dolichospermum } \\
\text { flos-aquae }\end{array}$ & 4.30 \\
\hline 10 & & Chwalim & 0.14 & $\begin{array}{l}\text { Dolichospermum } \\
\text { flos-aquae }\end{array}$ & $<0.15$ \\
\hline 11 & & Wojnowo & 226 & $\begin{array}{l}\text { Aphanizomenon } \\
\text { flos-aquae }\end{array}$ & $<0.15$ \\
\hline 12 & & Ostrzyce & 0.21 & $\begin{array}{c}\text { Dolichospermum } \\
\text { spiroides }\end{array}$ & $<0.15$ \\
\hline 13 & \multirow{6}{*}{$07 / 2012$} & Sadowo & 8.99 & $\begin{array}{c}\text { Dolichospermum } \\
\text { spiroides }\end{array}$ & $<0.15$ \\
\hline 14 & & $\begin{array}{l}\text { Lubiatów } \\
\text { (L2) }\end{array}$ & 8.25 & $\begin{array}{l}\text { Aphanizomenon } \\
\text { flos-aquae }\end{array}$ & $<0.15$ \\
\hline 15 & & Uście & 290 & $\begin{array}{l}\text { Aphanizomenon } \\
\text { flos-aquae }\end{array}$ & 3.70 \\
\hline 16 & & Chwalim & 3.23 & $\begin{array}{l}\text { Aphanizomenon } \\
\text { flos-aquae }\end{array}$ & $<0.15$ \\
\hline 17 & & Wojnowo & 650 & $\begin{array}{c}\text { Aphanizomenon } \\
\text { flos-aquae }\end{array}$ & $<0.15$ \\
\hline 18 & & Ostrzyce & 2.40 & $\begin{array}{c}\text { Dolichospermum } \\
\text { spiroides }\end{array}$ & $<0.15$ \\
\hline 19 & \multirow{5}{*}{$08 / 2012$} & Sadowo & 0.44 & $\begin{array}{c}\text { Planktothrix } \\
\text { agardhii }\end{array}$ & $<0.15$ \\
\hline 20 & & $\begin{array}{c}\text { Lubiatów } \\
\text { (L2) }\end{array}$ & 50.5 & $\begin{array}{c}\text { Aphanizomenon } \\
\text { flos-aquae }\end{array}$ & $<0.15$ \\
\hline 21 & & Uście & 233 & $\begin{array}{c}\text { Planktothrix } \\
\text { agardhii }\end{array}$ & 4.80 \\
\hline 22 & & Chwalim & 2.30 & $\begin{array}{c}\text { Planktothrix } \\
\text { agardhii }\end{array}$ & $<0.15$ \\
\hline 23 & & Wojnowo & 77.2 & $\begin{array}{l}\text { Planktothrix } \\
\text { agardhii }\end{array}$ & 1.61 \\
\hline
\end{tabular}


INFLUENCE OF CYANOBACTERIAL BLOOM ON FRESHWATER BIOCOENOSIS. USE OF BIOASSAYS FOR CYANOBACTERIAL MICROCYSTINS TOXICITY

ASSESSMENT

\begin{tabular}{|c|c|c|c|c|c|}
\hline 24 & & Ostrzyce & 8.41 & $\begin{array}{c}\text { Dolichospermum } \\
\text { flos-aquae }\end{array}$ & $<0.15$ \\
\hline 25 & \multirow{6}{*}{ 09/2012 } & Sadowo & 0.19 & $\begin{array}{c}\text { Planktothrix } \\
\text { agardhii }\end{array}$ & $<0.15$ \\
\hline 26 & & $\begin{array}{c}\text { Lubiatów } \\
\text { (L2) }\end{array}$ & 145 & $\begin{array}{l}\text { Microcystis } \\
\text { aeruginosa }\end{array}$ & 0.29 \\
\hline 27 & & Uście & 657 & $\begin{array}{l}\text { Planktothrix } \\
\text { agardhii }\end{array}$ & 5.00 \\
\hline 28 & & Chwalim & 1.03 & $\begin{array}{c}\text { Planktothrix } \\
\text { agardhii }\end{array}$ & $<0.15$ \\
\hline 29 & & Wojnowo & 221 & $\begin{array}{c}\text { Planktothrix } \\
\text { agardhii }\end{array}$ & 5.45 \\
\hline 30 & & Ostrzyce & 3.10 & $\begin{array}{c}\text { Planktothrix } \\
\text { agardhii }\end{array}$ & $<0.15$ \\
\hline 31 & \multirow{5}{*}{$10 / 2012$} & $\begin{array}{l}\text { Lubiatów } \\
\text { (L2) }\end{array}$ & 55.8 & $\begin{array}{l}\text { Microcystis } \\
\text { aeruginosa }\end{array}$ & 0.83 \\
\hline 32 & & $\begin{array}{c}\text { Lubiatów } \\
\text { (L3) }\end{array}$ & 403 & $\begin{array}{l}\text { Microcystis } \\
\text { aeruginosa }\end{array}$ & 271 \\
\hline 33 & & $\begin{array}{l}\text { Lubiatów } \\
\text { (L4) }\end{array}$ & 367 & $\begin{array}{l}\text { Microcystis } \\
\text { aeruginosa }\end{array}$ & 593 \\
\hline 34 & & $\begin{array}{l}\text { Lubiatów } \\
\text { (L5) }\end{array}$ & 346 & $\begin{array}{l}\text { Microcystis } \\
\text { aeruginosa }\end{array}$ & 17.7 \\
\hline 35 & & $\begin{array}{l}\text { Lubiatów } \\
\text { (L6) }\end{array}$ & 1130 & $\begin{array}{l}\text { Microcystis } \\
\text { aeruginosa }\end{array}$ & 826 \\
\hline
\end{tabular}

*Dominant species - the most numerous species in a total cyanobacteria numbers, nd - not detected

In the same time the presence of analyzed cyanotoxin was observed in three samples derived from Obrzyca River in the Uście locality and the concentrations were as follows: $1.20 ; 4.30$ and $3.70 \mu \mathrm{g} \cdot \mathrm{dm}^{-3}$.

In August, the analyzed toxin was additionally noted in the Obrzyca tributary in Wojnowo, where MC-LR value was $1.61 \mu \mathrm{g} \cdot \mathrm{dm}^{-3}$, and in Uście, where it amounted $4.80 \mu \mathrm{g} \cdot \mathrm{dm}^{-3}$. In September, intracellular examined microcystin concentratiom exceeded $5.00 \mu \mathrm{g} \cdot \mathrm{dm}^{-3}$ at Wojnowo and Uście on the river while on an outflow from Lake Sławskie (L2) it amounted $0.29 \mu \mathrm{g} \cdot \mathrm{dm}^{-3}$. The highest value of intracellular MC-LR was observed in Lake Stawskie in $20^{\text {th }}$ October and it equaled $826 \mu \mathrm{g} \cdot \mathrm{dm}^{-3}$ (Table 3, sample 35).

\subsection{Results of the tests using Daphnia magna}

Most methanol extract solutions (97\%) as well as MC-LR standard were nontoxic for Daphnia. Only methanol extract from Sławskie Lake bloom, where the microcystin level was the highest (Table 3, sample 35), was toxic at concentrations up to $6 \cdot 10^{3} \mu \mathrm{g} \cdot \mathrm{dm}^{-3}$ and 48 -h LC 50 was $3.09 \cdot 10^{3} \mu \mathrm{g} \cdot \mathrm{dm}^{-3}$ microcystins (Fig. 2). 


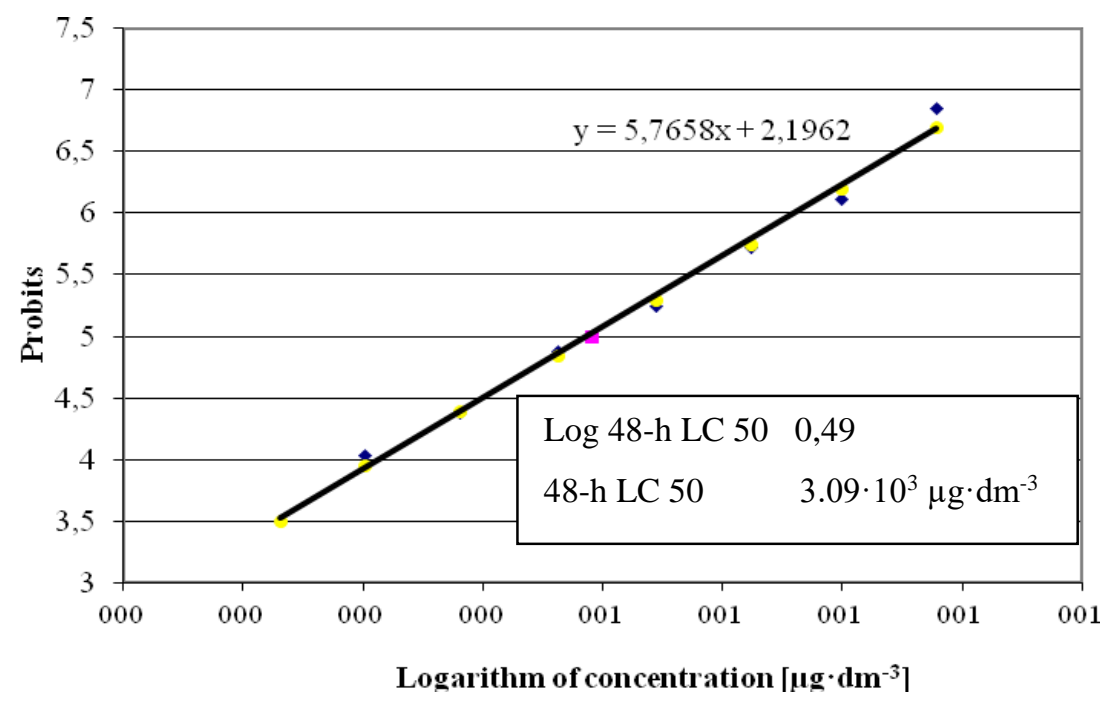

Fig 2. Calculation of LC 50 using graphical method for cyanobacterial bloom extract in Lake Sławskie (site L6) in October 2012 for Daphnia magna

\subsection{Results of the tests using Dugesia tigrina}

Also only methanol extract from Lake Sławskie bloom (Table 3, sample 35) was toxic for tubellarians after concentrations up to $6 \cdot 10^{3} \mu \mathrm{g} \cdot \mathrm{dm}^{-3} .240$-h LC 50 was $1.51 \cdot 10^{3} \mu \mathrm{g} \cdot \mathrm{dm}^{-3}$ microcystins (Fig. 3). The examined MC-LR standard was also non-toxic for turbellarians.

\subsection{Results of tests with bacteria}

\section{Escherichia coli}

It was observed that a growth in bacterial suspension optical density occurred with an increase in microcystin concentration (Fig. 4). Significant differences between $\mathrm{Bc}$ (optical density of the control sample after time t) and Bn (optical density of the examined sample after time $t$ ) were demonstrated using statistical analysis ( $\mathrm{t}_{\text {calc. }}$ 3.90; $\mathrm{t}_{\text {crit, }} 2.78 ; \mathrm{P}<0.05$ ). 
INFLUENCE OF CYANOBACTERIAL BLOOM ON FRESHWATER BIOCOENOSIS. 59 USE OF BIOASSAYS FOR CYANOBACTERIAL MICROCYSTINS TOXICITY ASSESSMENT

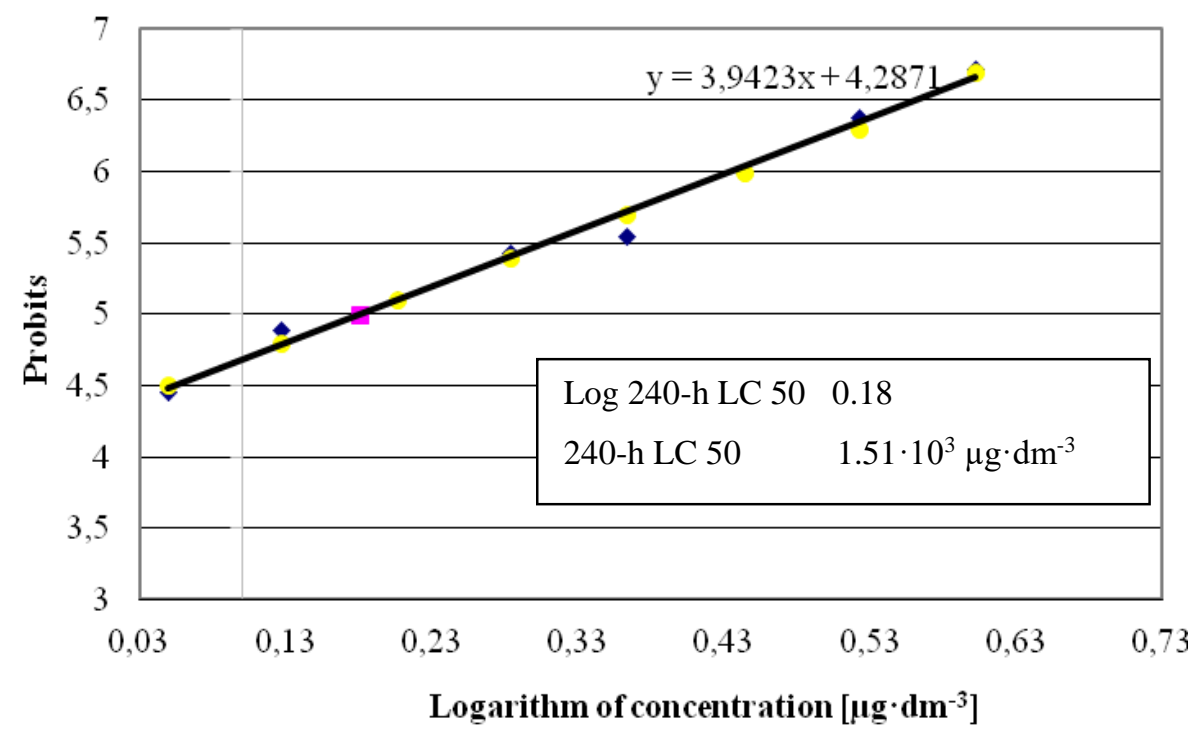

Fig. 3. Calculation of LC 50 using graphical method for cyanobacterial bloom extract in Lake Sławskie (siteL6) in October 2012 for Dugesia tigrina

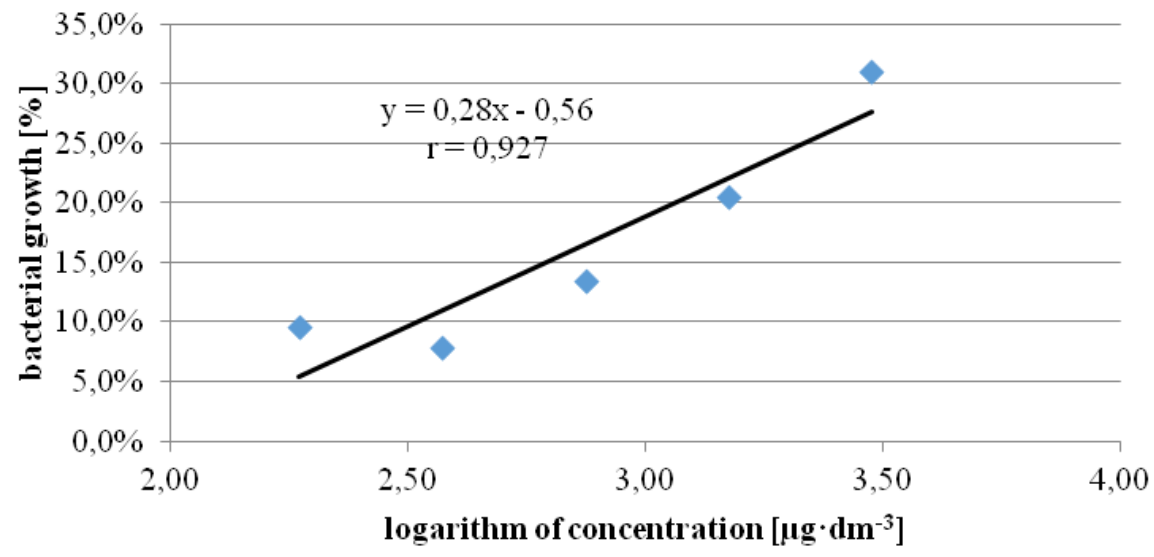

Fig. 4. Linear relationship between an increase in E. coli bacteria, and microcystin content growth in an extract

No reactions were demonstrated for the cells treatments with MC-LR standard of a concentration of $2 \cdot 10^{3} \mu \mathrm{g} \cdot \mathrm{dm}^{-3}$ in the tests with E. coli. A lack of significant differences between $\mathrm{Bc}$ and $\mathrm{Bn}$ was demonstrated using Student's t-test $(\mathrm{P}>0.05)$. 


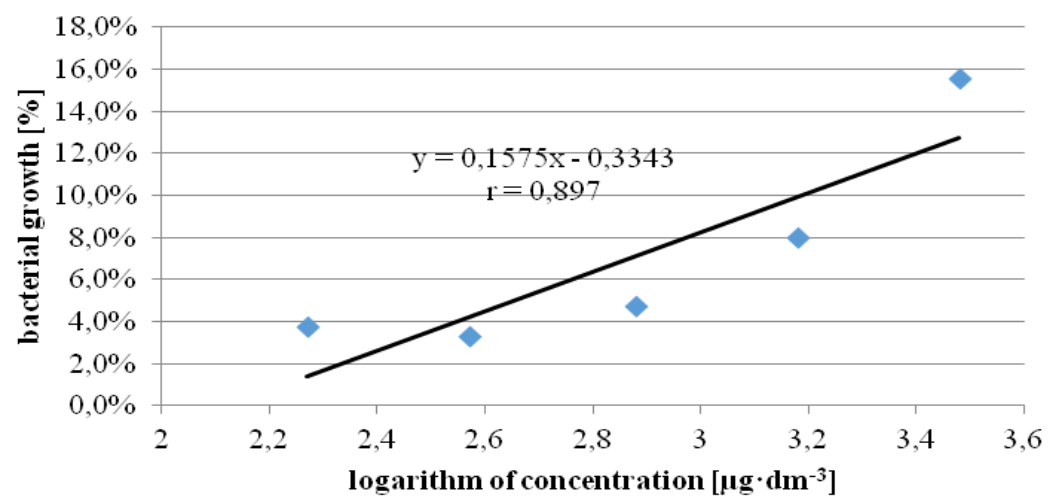

Fig. 5. Linear relationship between an increase in E. faecalis bacteria, and microcystin content growth in an extract

\section{Enterococcus faecalis}

Also in the case with streptococci it was observed not only lack of inhibition but also an increase of optical density bacterial suspension with increased microcystin concentration (Fig. 5). Significant differences between Bc (optical density of the control sample after time t) and Bn (optical density of the examined sample after time $t)$ were demonstrated using statistical analyses $\left(t_{\text {calc. }} 3.11\right.$; $\mathrm{t}_{\text {crit, }}$ 2.78; $\left.\mathrm{P}<0.05\right)$.

As in the tests with E. coli, E. faecalis cells did not demonstrate any reaction after incubation with MC-LR standard of a concentration of $2 \cdot 10^{3} \mu \mathrm{g} \cdot \mathrm{dm}^{-3}$. The lack of significant differences between $\mathrm{Bc}$ and $\mathrm{Bn}$ was demonstrated using Student's t-test $(\mathrm{P}<0.05)$.

\section{Pseudomonas fluorescens}

Pseudomonas fluorescens ATCC 13525 strain did not exhibit any reaction to the presence of microcystins. No effect of methanol extract concentration from Lake Sławskie (sample 35) or microcystin standard was observed on the growth or inhibition of bacterial cells proliferation.

\section{DISCUSSION}

Obrzyca River in two points: Uście and Wojnowo and Sławskie Lake constitute sampling sites where cyanobacterial blooms occured more frequently than in other investigated places.

Limnothrix redekei was mainly dominant in spring. Also domination of the species which prefers lower water temperature, was observed in Lake Syczyńskie in springtime [51]. This species is often observed in polytrophic reservoirs with 
very high nutrient concentration [52], typical in northern and central Europe [31] including Poland [16].

Planktothrix agardhii appeared to be a toxin-forming species in the Obrzyca River catchment, and it was dominant in late summer (August, September). During the blooming $\left(>500 \cdot 10^{3} \mathrm{org} \cdot \mathrm{dm}^{-3}\right)$ of this species, the amount of intracellular MC-LR exceeded $5 \mu \mathrm{g} \cdot \mathrm{dm}^{-3}$. Planktothrix blooms are mainly observed in moderate climatic zones [12]. Numerous toxic blooms of Planktothrix agardhii are also noted in Poland [12, 13, 18, 19, 33, 51]. In Siemianówka reservoir, the concentration of intracellular equivalent was as high as $174 \mu \mathrm{g} \cdot \mathrm{dm}^{-3}$ when the water temperature was $10.4^{\circ} \mathrm{C}$ [13], while in the Narew river the highest concentration of microcystins was observed in October 2008, i.e. $14.3 \mu \mathrm{g} \cdot \mathrm{dm}^{-3}$ [12]. P. agardhii species is considered especially dangerous for animals, since it is characterized by the biochemical ability to form even higher amounts of microcystin than other cyanobacteria of Microcystis sp. genus [27]. Additionally, the tendency for Chroococcales and Nostocales ousting by $P$. agardhii has been observed in Polish water reservoirs, which results in an increase in microcystin concentration in water [23].

Microcystis aeruginosa was dominant during water blooming in Lake Sławskie in October 2012. In 2009, this species was most often responsible for bloom formation in Poland [18]. Lake Sławskie is characterized by a long period of water retention, the theoretical water exchange in the whole lake basin is about 600 days [20]. In water reservoirs where water mixing is limited, water temperature exceeds $20^{\circ} \mathrm{C}$ and increases nutrient concentration the amount of Microcystis sp. may increase considerably within a few days. Such a phenomenon has been noted in a few reservoirs in Poland [33]. Microcystis sp. are able to synthesize hepatotoxins ie.: MC-LR, MC-RR, MC-YR [18].

The acute toxicity of methanol extract (with a microcystin content of $6 \cdot 10^{3} \mu \mathrm{g}$. $\mathrm{dm}^{-3}$ ) for $D$. magna in this study was evaluated as $3.09 \cdot 10^{3} \mu \mathrm{g} \cdot \mathrm{dm}^{-3}$ microcystins. It may be concluded from the literature data that daphnia exhibited lower sensitivity for MC-LR (in laboratory conditions), which was determined as $9.6 \div 21.4 \cdot 10^{3} \mu \mathrm{g} \cdot \mathrm{dm}^{-3}$ [8]. Hence, the conclusion is that either the susceptibility of tested D. magna individuals was high, or the toxicity of the microcystin mixture contained in the environmental sample was higher than single toxin MC-LR. According to Liebmann's toxicity scale [25], the result of LC $503.09 \cdot 10^{3} \mu \mathrm{g} \cdot \mathrm{dm}^{-3}$ for $D$. magna daphnia classifies microcystins as highly toxic. According to the Dockal and Soldan scale, the LC 50 result was evaluated as highly toxic, according to EPA moderately toxic, and according to EWG (ACE $89 / \mathrm{BE} 2 / \mathrm{D} 3$ ) as toxic ( $2^{\text {nd }}$ class of toxicity). The compared toxicity scales are taken from Lebkowska et al. [26]. DeMott et al. analyzed the acute toxicity of hepatotoxins (MC-LR and NOD) on crustacea: Diaptomus birgei (Copepod), 3 species of Cladocera: Daphnia hyalina, Daphnia pulex, Daphnia pulicaria. The 
lethal concentration MC-LR after $48 \mathrm{~h}$ was $21.4 \cdot 10^{3} \mu \mathrm{g} \cdot \mathrm{dm}^{-3}$ for $D$. pulicaria, $11.6 \cdot 10^{3} \mu \mathrm{g} \cdot \mathrm{dm}^{-3}$ for D. hyalina, $9.6 \cdot 10^{3} \mu \mathrm{g} \cdot \mathrm{dm}^{-3}$ for $D$. pulex, and $0.45 \cdot 10^{3}$ $\mu \mathrm{g} \cdot \mathrm{dm}^{-3}$ for $D$. birgei, respectively. The sensitivity of the examined bioindicators was lower for nodularin. The lethal concentration for this toxin originating from Nodularia spumigena after $48 \mathrm{~h}$ was $14.1 \cdot 10^{3} \mu \mathrm{g} \cdot \mathrm{dm}^{-3}$ for D. pulicaria, $3.9 \cdot 10^{3} \mu \mathrm{g} \cdot \mathrm{dm}^{-3}$ for D. hyalina, and $0.52 \cdot 10^{3} \mu \mathrm{g} \cdot \mathrm{dm}^{-3}$ for Diaptomus birgei [8]. Barros et al. examined the toxic effect of extracts of $M$. aeruginosa (strain IZANCYA 7, strain IZANCYA 2) on Cladocera: Daphnia longispina O.F. Müller, Daphnia magna, Daphnia pulex, Daphnia pulicaria and Ceriodaphnia pulchella Sars. The results of the study demonstrated intra- and inter-species differentiation of Cladocera on the toxic effect of aquatic cyanobacterial extracts. The least sensitive was $D$. magna (48-h LC 50 was $3.8 \cdot 10^{6} \mu \mathrm{g} \cdot \mathrm{dm}^{-3}$ extract from $M$. aeruginosa strain IZANCYA 7), and the most sensitive was D. pulicaria (48h LC 50 was $0.5 \cdot 10^{6} \mu \mathrm{g} \cdot \mathrm{dm}^{-3}$ extract from M. aeruginosa strain IZANCYA 2) [2]. Sierosławska et al. [46] studied the toxicity of cyanobacterial blooms which occurred in July 2007 in Lake Kunów. The abundance in the examined sample was $3.45 \cdot 10^{6} \mathrm{org} \cdot \mathrm{dm}^{-3}$ with a dominance of Microcystis sp. MC-LR concentration for that sample was $14.3 \cdot 10^{3} \mu \mathrm{g} \cdot \mathrm{dm}^{-3}$. Acute toxicity was determined using the Daphtoxkit $\mathrm{F}$ test on Daphnia pulex. The lethal concentration (LC 50) was determined based on the results obtained using the probit method. For D. pulex, 24-h LC 50 was estimated as $2.25 \cdot 10^{3} \mu \mathrm{g} \cdot \mathrm{dm}^{-3} \mathrm{MC}$ LR [46].

\section{Experiment with the application of new bioindicators for cyanobacterial bloom toxicity evaluation}

The acute toxicity of methanol extract (sample 35) for turbellarian was estimated as $1.05 \cdot 10^{3} \mu \mathrm{g} \cdot \mathrm{dm}^{-3}$ microcystins (MC-LR, MC-YR and MC-RR). The analysed sample were highly poisonous turbellarians, $2^{\text {nd }}$ category of poisons toxicity acc. to Liebmann [24].

In this study $D$. tigrina appeared to be more sensitive microcystin bioindicator than D. magna.

This sensitivity (240-h LC 50 amounting $1.05 \cdot 10^{3} \mu \mathrm{g} \cdot \mathrm{dm}^{-3}$ microcystins) is at a similar level as for Copepods. Acute toxicity 48-LC 50 for Diaptomus birgei was $0.45 \cdot 10^{3} \mu \mathrm{g} \cdot \mathrm{dm}^{-3} \mathrm{MC}-\mathrm{LR}$ [8], for Pseudodiaptomus forbesi it was $0.52 \mu \mathrm{g} \cdot \mathrm{dm}^{-3}$ MC-LR, and for Eurytemora affinis $1.55 \mu \mathrm{g} \cdot \mathrm{dm}^{-3} \mathrm{MC}-\mathrm{LR}$ [10].

The toxicity of the methanol extract of total microcystin concentration at $6 \cdot 10^{3}$ $\mu \mathrm{g} \cdot \mathrm{dm}^{-3}$ was examined in this study for three strains of bacteria. Extract toxicity for the analyzed invertebrate caused a growth of E. coli and E. faecalis cells. No examined bacteria strains demonstrated any reaction to MC-LR standard of a concentration of $2 \cdot 10^{3} \mu \mathrm{g} \cdot \mathrm{dm}^{-3}$, which may prove the overly low concentration of MC-LR used in the test. 
The stimulation of heterotrophic bacteria growth (Pseudomonas putida) affected by extracts containing cyanobacterial hepatotoxins and neurotoxins was also observed by Lahti et al. [22].

The inhibition or growth of four species of heterotrophic bacteria: Escherichia coli, Pseudomonas aeruginosa, Bacillus subtilis and Staphylococcus aureus was noted in the study of Ibraheem et al. [15] for cyanobacterial supernatants of eight cyanobacteria species: six belonging to Nostoc sp., and two of Anabaena sp. [15]. The reasons for biologically active secondary metabolite synthesis by cyanobacteria have not been fully recognized, but there is a hypothesis that the synthesis depends on special chemical signals created by bacteria, or the synthesis requires interactions between the cells of heterotrophic bacteria and cyanobacteria. An evaluation of cyanobacteria toxicity towards heterotrophic bacteria is sometimes difficult to assess, since the results obtained in biotests are different - from an inhibition up to a stimulation of heterotroph growth [24].

\section{CONCLUSIONS}

1. Toxic cyanobacterial blooms occur in the Obrzyca River catchment especially at point Uście and Wojnowo and in Sławskie Lake. During cyanobacterial bloom in Lake Sławskie (point L6) the maximal concentration of intracellular MC-LR equivalent was estimated as $826 \mu \mathrm{g} \cdot \mathrm{dm}^{-3}$. The dominant species in this time was Microcystis aeruginosa.

2. Analyzes of cyanobacterial abundance and taxonomic composition constitutes a very important tool for early warning against cyanotoxic danger especially in drinking water intakes.

3. Bioassays with Daphnia magna or Dugesia tigrina are applicable for the assessment of the toxicity of cyanobacterial blooms in which the concentration of microcystins is higher than $1 \cdot 10^{3} \mu \mathrm{g} \cdot \mathrm{dm}^{-3}$. Planarians were more sensitive than daphnids.

4. Bioassays with bacteria: Escherichia coli and Enterococcus faecalis are also useful tools for the assessment of the toxicity of cyanobacterial bloom. In order to verify the obtained results, this study should be continued.

\section{REFERENCES}

1. Adamovský O., Kopp R., Hilscherová K., Babica P., Paliková M., Navrátil S., Marśálek B., Bláha L.: Microcystin kinetics (bioaccumulation and elimination) and biochemical responses in common carp (Cyprinus carpio) and silver carp (Hypophthalmichthys molitrix) exposed to toxic cyanobacterial blooms, Environmental Toxicology and Chemistry, 26, 12 (2007) 2687-2693. 
2. Barros P., Fidalgo M.L., Soares S.A.M.V.M.: Resistance of cladoceran species to toxic Microcystis, Limnetica, 20, 1 (2001) 173-177.

3. Chen J., Xie P.: Seasonal dynamics of the hepatotoxic microcystins in various organs of four freshwater bivalves from the large eutrophic lake Taihu of subtropical China and the risk for human consumption, Environmental Toxicology, 20 (2005a) 572-584.

4. Chen J., Xie P.: Tissue distribution and seasonal dynamics of the hepatotoxic microcystins-LR and-RR in two freshwater shrimps, Palaemon modestus and Machrobrachium nipponensis, form a large, eutrophic lake of the subtropical China, Toxicon, 45 (2005b) 615-625.

5. Chen J., Xie P., Guo L., Zheng L., Ni L.: Tissue distribution and seasonal dynamics of the hepatotoxic microcystins-LR and - RR in a freshwater snail (Bellamya aeruginosa) from a large shallow, eutrophic lake the subtropical China, Environmental Pollution, 134 (2005) 423-430.

6. Chen J., Xie P.: Microcystin accumulation in freshwater bivalves from lake Taihu, China and potential risk to human consumption, Environmental Toxicolology and Chemistry, 26, 5 (2007) 1066-1073.

7. Czyżewska W.: Application of biological methods for the estimation of cyanotoxic threat in drinking water. Unpublished doctoral dissertation. Poland, University of Zielona Góra 2013.

8. DeMott W.R.., Zhang Q.-X., Carmichael W.W.: Effect of toxic cyanobacteria and purified toxins on the survival and feeding of copepod and three species of Daphnia, Limnology and Oceanography, 36, 7 (1991) 1346-1357.

9. EN ISO 7346-1:1997. Water quality -- Determination of the acute lethal toxicity of substances to a freshwater fish [Brachydanio rerio HamiltonBuchanan (Teleostei, Cyprinidae)] -- Part 1: Static method.

10. Ger K.A., Teh S.J., Goldman C.R.: Microcystin-LR toxicity on dominant copepods Eurytemora affinis and Pseudodiaptomus forbesi of the upper San Francisco Estuary, Science of the Total Environment, 407 (2009) 4852-4857.

11. Ger K.A., Urrutia-Cordero P., Frost P.C., Hansson L.A., Sarnelle O., Wilson A.E., Lürling M.: The interaction between cyanobacteria and zooplankton in a more eutrophic world, Harmful algae, (2016), http://dx.doi.org/10.1016/ j.hal.2015.12.005

12. Grabowska M., Mazur-Marzec H.: The effect of cyanobacterial blooms in the Siemianówka Dam Reservoir on the phytoplankton structure in the Narew River, Oceanological and Hydrobiological Studies, 40,1 (2011) 19-26.

13. Grabowska M., Pawlik-Skowrońska B.: Replacement of chroococcales and nostocales by oscillatoriales caused a significant increase in microcystin concentrations in a dam reservoir, Oceanological and Hydrobiological Studies, 37, 4 (2008) 23-33. 
INFLUENCE OF CYANOBACTERIAL BLOOM ON FRESHWATER BIOCOENOSIS. 65 USE OF BIOASSAYS FOR CYANOBACTERIAL MICROCYSTINS TOXICITY

ASSESSMENT

14. Ibelings B., Chorus I.: Accumulation of cyanobacterial toxins in freshwater seafood and its consequences for public health: A review, Environmental Pollution, 150, 1 (2007) 177-192.

15. Ibraheem I.B.M., Al-Othman M.R., Abdelraouf N.: Cyanobacterial extrametabolites against some pathogenic bacteria, African Journal of Microbiology Research, 6, 38 (2012) 6720-6725.

16. Jakubowska N., Zagajewski P., Gołdyn R.: Water blooms and cyanobacterial toxins in lakes, Polish Journal of Environmental Studies, 22, 4 (2013) 10771082.

17. Jurczak T., Tarczyńska M., Karlsson K., Meriluoto J.: Characterization and Diversity of Cyanobacterial Hepatotoxins (Microcystins) in Blooms from Polish Freshwaters Identified by Liquid Chromatography - Electrospray Ionisation Mass Spectrometry, Chromatografia, 59 (2004) 571-578.

18. Kobos J., Błaszczyk A., Hohlfeld N., Toruńska-Sitarz A., Krakowiak A., Hebel A., Sutryk K., Grabowska M., Toporowska M., Kokociński M., Messyasz B., Rybak A., Napiórkowska-Krzebietke A., Nawrocka L., Pełechata A., Budzyńska A., Zagajewski P., Mazur-Marzec H.: Cyanobacteria and cyanotoxins in Polish freshwater bodies, Oceanological and Hydrobiological Studies, 42, 4 (2013) 358-378.

19. Kokociński M., Stefaniak K., Izydorczyk K., Jurczak T., Mankiewicz-Boczek J., Soininen I.: Temporal variation in microcystin production by Planktothrix agardhii (Gomont) Anagnostidis and Komárek (Cyanobacteria Oscillatoriales) in temperate lake, Annales de Limnologie - International Journal of Limnology, 47 (2011) 363-371.

20. Kowalczak P., Krauze G., Siudak R.: New methods of measurements and analyses applied in limnological researches. Case study - Stawskie Lake, Warszawa, IMGW 2007.

21. Kulasooriya S.A.: Cyanobacteria: Pioneers of Planet Earth, Ceylon Journal of Science, 40, 2 (2011) 71-88.

22. Lahti K., Rapala J., Kivimäki A.L., Kukkonen J., Niemelä M., Sivonen K.: Occurrence of microcystins in raw water sources and treated drinking water of Finnish waterworks, Water Science and Technology, 43, 12 (2001) 225228.

23. Larson D., Ahlgren G., Willén E.: Bioaccumulation of microcystins in the food web: a field study of four Swedish lakes, Inland Waters, 4 (2014) 91-104.

24. Lawton L.A., Marŝálek B., Padisák J., Chorus I.: Determination of cyanobacteria in the laboratory, in: Toxic cyanobacteria in water. A guide to their public health consequences. Monitoring and management, edit. I. Chorus , J. Bartram, London and New York, Taylor \&Francis 1999, 347-367. 
25. Liebmann H.: Handbuch der Frischwasser und Abwasserbiologie. Jena, G. Fischer Verlag 1962.

26. Łebkowska M., Załęska -Radziwiłł M., Słomczyńska B.: Environmental Toxicology. Warszawa, Oficyna Wydawnicza Politechniki Warszawskiej 2004.

27. Mankiewicz-Boczek J., Izydorczyk K., Romanowska-Duda Z., Jurczak T., Stefaniak K., Kokociński M.: Detection and monitoring toxigenicity of cyanobacteria by application of molecular methods, Environmental Toxicolology, 21 (2006) 380-387.

28. Markowski J., Symonowicz C., Stanisławiak R.: On the Utility of the Microsieves Operated by the Zawada Water Treatment Plant, Ochrona Srodowiska, 1, 60 (1996) 35-38.

29. Mitsoura A., Kagalou I., Papaioanou N., Berillis P., Mente E., Papadymitriou T., Kormas K.: The presence of microcystins in fish Cyprinus carpio tissues: a histopatological study, International Aquatic Research, 5, 8 (2013) 1-6.

30. Mur L.R., Skulberg O.M., Utkilen H.: Cyanobacteria in the environment, in: Toxic cyanobacteria in water. A guide to their public health consequences. Monitoring and management, edit. I. Chorus, J. Bartram, London and New York, Taylor \&Francis 1999, 15-40.

31. Ott I. Nöges P., Laugaste R., Köiv T.: Occurrence of Limnothrix redekei VAN GOOR in Estonian lakes, Algological Studies, 109 (2003) 455-468.

32. Papadimitriou T., Kagalau I., Stalikas C., Pilidis ., Leonardos I.D.: Assessment of microcystin distribution and biomagnification in tissues of aquatic food web compartments from a shallow lake and evaluation of potential risks to public health, Ecotoxicology, 21 (2012) 1155-1166.

33. Pawlik-Skowrońska B., Toporowska M.: Blooms of toxin-producing Cyanobacteria - a real threat in small dam reservoirs at the beginning of their operation, Oceanological and Hydrobiological Studies, 40, 4 (2011) 30-37.

34. Pawlik-Skowrońska B., Toporowska M., Rechulicz J.: Simultaneous accumulation of anatoxin-a and microcystins in three fish species indigeous to lake affected by cyanobacterial blooms, Oceanological and Hydrobiological Studies, 41, 4 (2012) 53-65.

35. Pérez-Morales A., Sarma S.S., Nandini S.: Feeding and filtration rates of zooplankton (rotifers and cladocerans) fed toxic cyanobacterium (Microcystis aeruginosa), Journal of Environmental Biology, 35 (2014) 10131020.

36. Piontek M.: Toxicity assessment of 28 mineral and organic chemical compounds on the basis of test with Daphnia magna Straus, Environmental Engineering, 5 (1997) 49-59.

37. Piontek M.: Use of the planarian Dugesia tigrina Girard in the studies of acute intoxication, Polskie Archiwum Hydrobiologii, 46 (1999a) 41-48. 
38. Piontek M.: Use of the planarian Dugesia tigrina Girard in the studies of acute intoxication of organic substances, Polskie Archiwum Hydrobiologii, 46 (1999b) 331-338.

39. Piontek M.: Moulds and estimation of mycotoxic threat in dwelling buildings, Zielona Góra, University of Zielona Góra 2004.

40. Piontek M.: Use of planarian Dugesia tigrina Girard bioassay for assessing the toxicity of sterigmatocystin produced by Aspergillus versicolor Tiraboschi, Environmental Protection and Engineering, 36, 1 (2010) 65-71.

41. Piontek M., Bednar K.: Permanent control of test organism physiological state in toxicological investigation. Condition test, in: Ecotoxicology in Environmental Protection, edit. B. Kołwzan, K. Grabas, Szklarska Poręba, PZITS 2008, 313-318.

42. Piontek M., Czyżewska W.: Efficiency of drinking water treatment processes. Removal of phytoplankton with special consideration for cyanobacteria and improving physical and chemical parameters, Polish Journal of Environmental Studies, 21, 6 (2012) 273-281.

43. Piontek M., Czyżewska W., Mankiewicz-Boczek J.: The occurence of cyanobacteria blooms in the Obrzyca River catchment area (Poland), a source of drinking water, Polish Journal of Environmental Studies, 3, 26 (2017) (in print).

44. Piontek M., Grochowiecka W.: Choice of methods for toxicological studies on the basis of hydrobiological analysis of blue-green in the water intakes, Chemical Review, 87, 5 (2008) 2-6.

45. Renaud S.L.B., Pick F.R., Fortin N.: Effect of light intensity on the relative dominance of toxigenic and nontoxigenic of Microcystin aeruginosa, Applied and Environmental Microbiology, 77, 19 (2011) 7016-7022.

46. Sierosławska A., Rymuszka A., Adamczyk A., Bownik A., Skowroński T. Assessment of the toxicity of cyanobacterial bloom in the fish pond near Lublin. in: Ecotoxicology in Environmental Protection, edit. B. Kołwzan, K. Grabas, Szklarska Poręba, PZITS 2008, 361-365.

47. Sipiä V.O., Sjövall O., Valtonen T., Barnaby D.L., Codd G.A., Metcalf J.S., Kilpi M., Mustonen O., Meriluoto J.A.O.: Analysis of nodularin-R in eider (Somateria mollissima), roach (Rutilus rutilus L.), and flounder (Platichthys flesus L.) liver and muscle samples from the western Gulf of Finland, northern Baltic Sea, Environmental Toxicology and Chemistry, 25, 11 (2006) 28342839.

48. Traczewska T. Biomonitoring mutagenności mikrozanieczyszczeń wody do picia, Wrocław, Oficyna Wydawnicza Politechniki Wrocławskiej 2002.

49. Weber E.: Grundriss der biologischen Statistik für Naturwissenschaftler, Landwirte und Mediziner. Jena : G. Fischer Verlag 1972. 
50. Wilson A.E. Sarnelle O., Tillmanns A.R.: Effects of cyanobacterial toxicity and morphology on the population growth of freshwater zooplankton: Metaanalyses of laboratory experiments, Limnology and Oceanography, 51, 4 (2006) 1915-1924.

51. Wiśniewska M., Krupa D., Pawlik-Skowrońska B., Kornijów R.: Development of toxic Planktothrix agardhii (Gom.) Anagn. et Kom. and potentially toxic algae in the hypertrophic Lake Syczyńskie (Eastern Poland), Oceanological and Hydrobiological Studies, 36 (2007) 173-179.

52. Zębek E.: Long-term cyanobacterial dynamics as related to physicochemical water parameters in a restored urban lake, Journal of Elementology, 21, 1 (2016) 269-282.

\section{WPŁYW ZAKWITÓW SINIC NA SŁODKOWODNĄ BIOCENOZĘ. ZASTOSOWANIE BIOTESTÓW DO OCENY TOKSYCZNOŚCI MIKROCYSTYN SYNTETYZOWANYCH PRZEZ SINICE}

\section{Streszczenie}

Zagadnienia przedstawione $\mathrm{w}$ niniejszym artykule dotyczą bardzo ważnego problemu występowania zakwitów sinic $\mathrm{w}$ wodach powierzchniowych wykorzystywanych do celów wodociągowych. Celem pracy była ocena cyjanotoksycznego ryzyka w zlewni rzeki Obrzyca (w tym jeziora Sławskiego będącego początkiem rzeki), która jest źródłem wody do picia dla mieszkańców Zielonej Góry. W celu oceny toksyczności sinic przeprowadzono badania toksykologiczne przy użyciu bezkręgowców wodnych (Daphnia magna i Dugesia tigrina) oraz bakterii heterotroficznych (Escherichia coli, Enterococcus faecalis, Pseudomonas fluorescens). Próbki do badań pobierano od maja do października w 2012 roku. Ekstrakt metanolowy z zakwitu sinic (dominacja gatunku Microcystis aeruginosa) w J. Sławskim, gdzie ilość mikrocystyn była największa, był toksyczny dopiero po zatężeniu do $6 \cdot 10^{3} \mu \mathrm{g} \cdot \mathrm{dm}^{-3}$. Stężenie letalne (48-h LC 50) dla Daphnia magna wyniosło $3,09 \cdot 10^{3}$ a dla Dugesia tigrina (240-h LC 50) było równe $1,51 \cdot 10^{3} \mu \mathrm{g} \cdot \mathrm{dm}^{-3}$ mikrocystyn (MC-LR, MC-YR i MC-RR). Ten sam ekstrakt stymulował wzrost komórek Escherichia coli i Enterococcus faecalis.

Słowa kluczowe: sinice, toksyczność cyjanotoksyny, biotesty

Editor received the manuscript: 21.04.2016 